\title{
INFLATION INERTIA IN TURKISH ECONOMY: DYNAMIC CONDITIONAL CORRELATION-GENERALIZED AUTOREGRESSIVE CONDITIONAL HETEROSKEDASTICITY (DCC-GARCH) AND WAVELET ANALYSIS
}

DOI: 10.17261/Pressacademia.2020.1306

JEFA- V.7-ISS.4-2020(3)-p.324-337

Caner Ozdurak $^{1}$, Cengiz Karatas ${ }^{2}$

${ }^{1}$ Yeditepe University, Department of Financial Economics, Atasehir, Istanbul, Turkey. caner.ozdurak@yeditepe.edu.tr, ORCID: 0000-0003-0793-7480

${ }^{2}$ Yeditepe University, Department of Financial Economics, Atasehir, Istanbul, Turkey cengiz.karatas@yeditepe.edu.tr, ORCID: 0000-0001-7554-801X

Date Received: October 10, 2020

Date Accepted: December 10, 2020

To cite this document

Ozdurak, C., Karatas, C., (2020). Inflation inertia in Turkish economy: dynamic conditional correlation-generalized autoregressive conditional heteroskedasticity (DCC-GARCH) and wavelet analysis. Journal of Economics, Finance and Accounting (JEFA), V.7(4), p.324-337.

Permanent link to this document: http://doi.org/10.17261/Pressacademia.2020.1306

Copyright: Published by PressAcademia and limited licensed re-use rights only.

\section{ABSTRACT}

Purpose - In this paper, aftermath of the FX shock experienced in August 2018, as a result of increasing production costs the evolution of inflation inertia is examined

Methodology - We examined the endogenous nature of inflation and the increase in producer prices after exchange rate changes and the effect of monetary policies on inflation by using impulse-response analysis for the short term and DCC-GARCH and wavelet analysis for the medium-long term

Findings- The dynamic conditional correlation coefficients between CPI-MS were not significant even at the $1 \%$ significance level (excluding $\mathrm{Q}_{2}$ in the CPI-MS model for the 2006-2020 June period) but $\mathrm{Q}_{2}$ were negative. It is observed that the persistence degree of short-term shocks is higher than the persistence degree of variances on the dynamic conditional correlation. Therefore, dynamic conditional correlation is less affected by past variances depending on time. Moreover, Wavelet coherence (WTC) figures show that the series have very high coherence areas in the post-currency shock period.

Conclusion- As we can see in the GARCH models, it would not be wrong to link this situation to the palliative and short-term monetary policies of the Central Bank. The WTC results are also in line with the Impulse-Response and VAR Analysis results, and especially in the August 2018August 2020 period, CPI-PPI and CPI-Money Supply and that inflation is affected by PPI and money supply.

Keywords: inflation, DCC-GARCH, impulse-response, wavelet analysis, monetary policy JEL Codes: E31, E52, C32

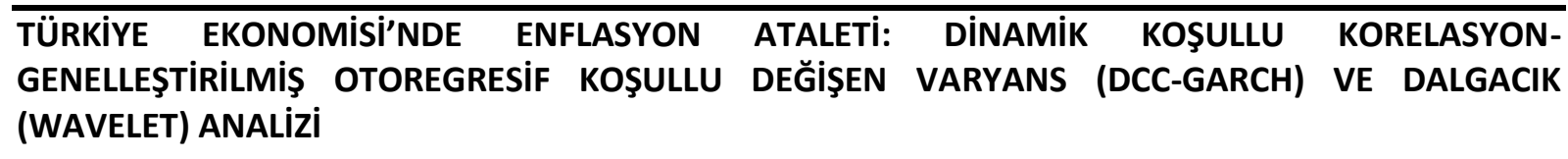

\section{ÖZET}

Amaç - Türkiye ekonomisinde 2018 Ağustos ayında yaşanan kur şoku sonrası ve Covid-19 salgınının da etkisiyle üretim maliyetlerinin artması sonucu enflasyon ataletinin dönüşümü incelenmektedir.

Yöntem - Bu çalışmamızda enflasyonun endojen yapısını ve kurdaki geçişmeler sonrası üretici fiyatlarının artması ve uygulanan para politkalarının enflasyona etkisini kısa vadede için etki-tepki analizleri ile orta-uzun vade için ise DCC-GARCH ve dalgacık (wavelet) analizi yöntemlerini kullanarak irdeledik

Bulgular- TÜFE-MS arasındaki dinamik koşullu korelasyon katsayıları \%1 anlamlılık düzeyinde (2006-2020 Haziran dönemi için TÜFE-MS modelindeki @2 hariç) bile anlamlı bulunmamıştır fakat @2 negatiftir. Dinamik koşullu korelasyon üzerinde kısa dönem şokların kalıcılık derecesi varyansların kalıcılık derecesine göre daha yüksek olduğu görülmektedir. Dolayısıyla, dinamik koşullu korelasyon zamana bağlı olarak geçmiş varyanslardan daha az etkilenmektedir. Dalgacık uyumu (WTC) figürleri, kur şoku sonrası dönemde serilerin çok yüksek koherens alanlarına sahip olduğunu göstermektedir.

Sonuç- GARCH modellerinde de gördüğümüz gibi, Merkez Bankası'nın palyetif ve kısa vadeli para politikalarına bağlamamız çok da yanlış olmayacaktır, WTC sonuçları da Etki-Tepki ve VAR Analizi sonuçları ile uyumludur ve özellikle Ağustos 2018-Ağusotos 2020 döneminde TÜFEÜFE ve TÜFE-ParaArzı'nın birlikte hareket ettiğini ve enflasyonun, ÜFE ve para arzından etkilendiğini ifade etmektedir.

Anahtar Kelimeler: Enflasyon, DCC-GARCH, impulse-response, wavelet analizi, para politikası JEL Kodları: E31, E52, C32 


\section{GiRiş}

2018 Ağustos kur krizinde Türkiye Cumhuriyet Merkez Bankası'nın tek seferde yüksek bir faiz artışı ile hamle yapmayarak zamana yaydığı ve palyatif önlemlerle yönetmeye çalıştığı süreç swap işlemleri gibi daha da karmaşık araçlarla yüzdürüldü. Sonuç olarak pandeminin de etkisiyle faizlerin de kamu bankalarının yarattı̆̆ı ikincil kredi piyasaları ile yapay bir şekilde düşürülmesi sonucu taşıt, ihtiyaç, konut ve ticari kredi faizlerinin sürekli düşürülmesi tüketim odaklı bir ekonomik yapı oluşturdu. Son dönemlerde de Merkez Bankası net bir faiz artışı yapmak yerine gecelik faiz oranları ve karşılık oranlarıyla dolaylı ayarlar yaparak süreci yönetmeye çalışsa da eknomide sürekli hale gelen bir durgunluk oluştu ve ekonomi sürdürülebilir üretim ve istihdam kabiliyetini kaybetme noktasına geldi (Figür 1).

Figür 1: Sanayi Üretim Endeksi ve TÜFE

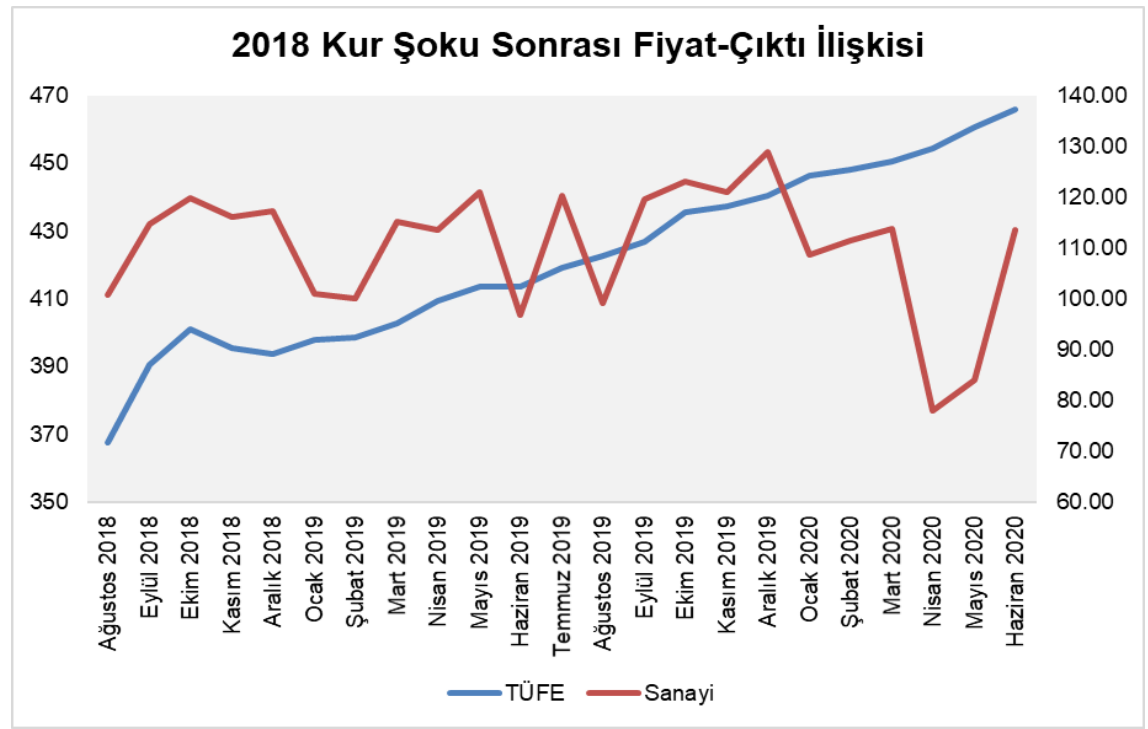

Fisher'in değişim denkleminden hareket edersek ekonominin genel dengesinii parasal ilişkileri de işine içine sokarak göstermiş oluruz. Bu kapsamda;

$$
M V=P Q
$$

Bu eşitlikte M para arzını, V paranın dolanım hızını (yani her bir para biriminin yıl içinde kaç kez el değiştirdiğini), P fiyatlar genel düzeyini, Q ekonomide üretilen mal ve hizmetleri gösterir. Odağımız enflasyon olduğu için denklemi P'yi yalnız bırakacak şekilde tekrar düzenlersek;

$$
P=\frac{M V}{Q}
$$

Klasik genel denge yaklaşımına göre ilerlersek emek piyasasının esnek nominal ücretler sayesinde daima dengede olduğunu savunabiliriz. Kısa vadede ülkedeki sermayesi stoku dışsal bir değişken olarak kabul edilirse üretim ve emeğin fiyatı olan reel ücretler piyasada belirlenir. Bu bağlamda söz konusu üretim dengesi aşağıdaki gibi tanımlanabilir;

$$
\begin{aligned}
& P Q=F(K, L) \\
& L^{S}=G\left(\frac{W}{P}\right) \\
& L^{d}=H\left(\frac{W}{P}\right)
\end{aligned}
$$

[3] numaralı denklem üretim fonksiyonudur. $P Q$ toplam reel üretimi, $L$ üretimde kullanılan emek miktarını, $K$ ise üretimde kullanılan toplam sermaye miktarını gösterir. [4] numaralı denklem emek arzının $\left(L^{S}\right)$ reel ücretlerle $\left(\frac{W}{p}\right)$ pozitif bir ilişki içinde olduğunu [5] numaralı denklem de gösterir emek talebinin $\left(L^{d}\right)$ reel ücretler negatif ilişki içinde olduğunu gösterir. Buna göre denklem [3]'ü denklem [4]'ü kullanarak tekrar yazarsak;

$$
Q=\frac{F\left(K, G\left(\frac{w}{p}\right)\right)}{P}
$$


Parasal dengeye baktığımızda ise aşağıdaki şekilde tanımlanmaktadır

$$
\frac{M}{P}=h(r, Y)
$$

Denklem [7]'de M para arzı ve talebini (dengede arz ve talep eşittirler), $h(r, Y)$ ise para talebinin faiz oranı ( $r$ ) ile negatif, gelir düzeyiyle pozitif bir ilişkide olduğu gösterir. Denklem [7]'yi tekrar düzenlersek;

$$
M=P * h(r, Y)
$$

Denklem [2], [6], ve [8]' birleştirirsek denklem [9]'u elde ederiz

$$
P=\frac{P V * h(r, Y)}{\frac{F\left(K, G\left(\frac{w}{p}\right)\right)}{P}}
$$

Denklem [9]'u da tekrar düzenlersek;

$$
P=\frac{P V^{2}(h(r, Y))}{F\left(K, G\left(\frac{w}{p}\right)\right)}
$$

$Q$ ile tanımladığımız toplam çıktıyı A toplam faktör verimliliği, L emek girdisi, $K$ ise sermaye, $\alpha$ ve $\beta$ ise emek ve sermayenin çıktı esnekliği olacak şekilde Cobb-Douglas üretim fonksiyonu ile tekrar tanımlar isek:

$$
Q=A L^{\alpha} K^{1-\alpha}
$$

Burada hareketle denklem [10]'u deklem [11]'i kullanarak tekrar dizayn edersek;

$$
P=\frac{P V^{2}(h(r, Y))}{A\left(G\left(\frac{w}{p}\right)\right)^{\alpha} K^{1-\alpha}}
$$

Sermayeyi de reel faizin bir fonksiyonu olarak $K=I\left(\frac{r}{p}\right)$ tanımlar ve denklem [12]'de yerine koyarsak:

$$
P=\frac{P V^{2}(h(r, Y))}{A\left(G\left(\frac{w}{p}\right)\right)^{\alpha}\left(I\left(\frac{r}{p}\right)\right)^{1-\alpha}}
$$

Son olarak Y'yi tüketim(C), kamu harcamaları(G), yatırım(I) ve net iharacat (X-M) cinsinden yazıp denklem [13]'ü tekrar düzenlersek nihai $P$ eşitliğimize aşağıdaki şekilde ulaşırız;

$$
P=\frac{P V^{2}(h(r,(C+I+G+(X-M)))}{A\left(G\left(\frac{w}{p}\right)\right)^{\alpha}\left(I\left(\frac{r}{p}\right)\right)^{1-\alpha}}
$$

Denklem [14]'ten hareketle öncelikle fiyatlar genel düzeyinin endojen yapısını görmekteyiz. Bununla birlikte faizin direk müdahale ile fiyatlar genel seviyesine lineer olmayan bir etkisi olduğu da görülebilirken faizlere yapılacak bir müdahalenin sermaye maliyeti üzerinden toplam çıktıya da etki edeceği açıktır.

Enflasyon ataleti, geçmiş döneme ait enflasyon, cari dönem enflasyonunun önemli bir parçasıdır. Enflasyonun gecikmeli değerleri ile temsil edilen enflasyon ataleti iki şekilde etkisini göstermektedir: Eğer geçmiş döneme ait enflasyon maliyetli olmuş ise, cari dönem enflasyonu daha düşük olabilmektedir. İkinci olarak enflasyonist beklentiler geçmişe yönelik ise, görece daha yüksek düzeyli geçmiş dönem enflasyonu dezenflasyon çabalarını daha maliyetli kılmakta, bu nedenle daha yüksek enflasyon düzeyi ile son bulmaktadır (Narayan vd.,2011:919; Cottarelli vd., 1998).

Merkez Bankasının politika faizini yapay bir şekilde düşürmesi, kamu bankaları vasıtası ile piyasa faizlerini indirmiş algısı yaratması, bir süre sonra bankalarda Türk lirası mevduat bulunamamasına neden olur. Bunun nedeni yapay bir şekilde düşük faizlere ragmen yüksek enflasyon ortamında reel getiri sağlayamayan mevduat sahibinin ya döviz mevduatına ya da altın gibi emtialara yatırım yapması olarak karşımıza çıkar.

Aynı şekilde döviz kurlarını serbest piyasa ekonomisinin mekanizmaları dışında baskıda tutulursa bir noktada rezervler tükenip kur yönetilememe noktasına geldiğinde olumsuz etkisi yapay olumlu etkisinden çok daha fazla olmaktadır. Bu bağlamda 2018 ağustos sonrası piyasada enflasyonu düşürmek için öncelikle kura baskı yapılmaya çalışıldı. Zira kurlar arttıkça döviz fiyatlarına bağlı mal ve hizmetlerin fiyatı da ona göre artmaya başlar. Mal ve hizmet fiyatlarının artması önce üretici fiyatlarına ve daha sonra da biraz gecikmeli olarak tüketici fiyatlarına yansır. 
Enflasyon ataleti oluştuğunda politika üretmek daha da zorlaşır. Ekonomide spekülatif işlemler öne çıkar, üretimden kaçılır, işsizlik yükselir, gelir dağılımı bozulur. Dolayısıyla ekonomi bu işleyişten çok ciddi şekilde yara alır. Bugün (03.11.2020) itibari ile bu son cümlede bahsettiğimiz her unsuru tecrübe etmekteyiz.

Bu çalışmamızda enflasyonun endojen yapısını ve kurdaki geçişmeler sonrası üretici fiyatlarının artması ve uygulanan para politkalarının enflasyona etkisini kısa vadede için etki-tepki analizleri ile orta-uzun vade için ise DCC-GARCH ve dalgacık (wavelet) analizi yöntemlerini kullanarak irdeleyeceğiz. Hem kullandığımız yöntemlerin çeşitliliği hem de Covid-19 dönemi etkisin de içeren güncel bir araştırma olması sebebiyle literatüre katkı sağlayacağını düşünüyoruz.

\section{LITERATÜR}

Üretici fiyatlarının, döviz şokları ve kur geçişmeleri, para politikalarının enflasyona etkileri üzerine hem yerli hem yabancı kaynaklarda oldukça geniş bir literatür mecvut. Caporale vd (2002) Ocak 1976- Nisan 1999 dönemini içeren TEFE ve ÜFE verilerini kullanarak Toda Yamamato Nedensellik Analizi ile G7 ülkelerini analiz etmiş ve Üfe'den Tüfe'ye doğru tek yönlü nedensellik ilişkisi elde edilmiştir. Dorestani ve Arjomand (2006) ABD'nin 1960-2005 dönemi için ÜFE-TEFE verilerini eş bütünleşme testleri ile araştırmış fakat ilişki bulamamışlardır. Akçay (2011) seçilmiş AB ülkeleri (İsveç, Fransa, Almanya, Finlandiya, Hollanda) için Ağustos 1995-Aralık 2007 dönemini içeren TEFE ve ÜFE verilerini kullanarak, Toda Yamamato nedensellik analizi ile test etmiş ve Finlandiya ve Fransa'da Üfe'den Tüfe'ye doğru tek yönlü; Almanya'da çift yönlü nedenselik ilişki tespit edilirken; Hollanda ve İsveç'te nedensellik ilişkisi tespit edilememiştir

Saraç ve Karagöz (2010) 1994-2009 yıllarını içeren TEFE-ÜFE verilerini Eş Bütünleşme ve ARDL Sınır Testi kullanarak analiz ederek kısa ve uzun dönemde ÜFE' den TEFE'ye doğru tek yönlü nedensellik ilişkisi elde etmiştir. Abdioğlu ve Korkmaz (2012) 2003-2012 yıllarını içeren TEFE-ÜFE verilerini nedensellik analizleri ile test edip uzun dönemde değişkenler arası ilişki bulamamış, kısa dönemde değişkenler arası çift yönlü ilişki elde etmiştir.

Kasım 2000 ve Şubat 2001 'de yaşanan krizlerin etkisiyle; net iç varlık uygulamasına devam edilememesi, yüksek reel faizin yanı sıra ilave risk primi verilmesinin gündeme gelmesi ve tüm bunların yanı sıra döviz cephesinde yaşanan olumsuzluklar nedeniyle bu döneme ilişkin enflasyon artış eğilimini sürdürmüştür (Karpat-Çatalbaş, 2007). Türkiye için 2009:01-2018:12 dönemi enflasyon ile enflasyonu etkileyen makroekonomik faktörler arasındaki uzun dönemli ilişkinin varlığı üzerine yapılan analiz Türkiye'de enflasyon üzerinde en etkili olan faktörün döviz kuru olduğunu göstermiştir (Demirgil, 2019). Türkiye'de uzun dönemde döviz kurundaki yüzde 1'lik artışın TüFE cinsinden yurtiçi fiyatlarda yüzde 0.72 ve yüzde 0.91 oranı arasında artışa yol açtı̆̆ı ve böylece döviz kurunun enflasyon üzerinde geçiş etkisinin anlamlı fakat 1'den küçük olduğu sonucuna varılmıştır (Altıntaş, 2014). 1980-2014 dönemi için Türkiye ekonomisi bakımından, enflasyon ve para arzı arasında uzun dönemde anlamlı ve pozitif bir ilişki bulunurken, enflasyon ve bütçe açığı arasında anlamlı bir ilişki bulunamamıştır (Kaya ve Öz, 2016).

Para ve fiyatlar arasındaki nedensellik ilişkisi paradan fiyatlara doğrudur ve bu değişkenler arasında bir geri etkileşim (feedback) ilişkisi çift yönlüdür (İslatince, 2017). Grinsted ve arkadaşları (2004) iki zaman serisi için dalgacık analizine odaklanarak dalgacık uyumu (wavelet coherence-WTC) ve çapraz dalgacık dönüşümü (cross wavelet transform) uygulamalarını geliştirdiler. Tiwari (2012) çapraz dalgacık analizi ile Alman ekonomisindeki petrol fiyatları, endüstriyel üretim ve enflasyon ile Hindistan ekonomisindeki faiz oranları ve hisse fiyatları arasındaki ilişkiyi analiz etmiştir.

\section{YÖNTEM}

Çalışmada öncelike ekti-tepki analizlerindeki sonuçlara göre ilgili değişkenlerin tepkilerine bakılarak GARCH modellerinin girdileri belirlenmiştir. Sonrasında ise iki farklı dönem için oluşturulan Dinamik Koşullu Korelasyon GARCH modelleri ile iki veriler arasındaki dinamik ilişkiye odaklanılmıştır. Son olarak da DCC-GARCH modelleri Dalgacık (Wavelet) analizleri ile sınanmıştır.

\subsection{Etki-Tepki Analizleri}

Çoğunlukla VAR modellerini iktisadi olarak yorumlamak zordur. Bu nedenle çoğu zaman VAR analizi yapılırken, model parametreleri için değil etki tepki fonksiyonu ve varyans araştırması için kullanılmaktadır. Etki tepki fonksiyonu VAR modelindeki endojen değişkenlerin hata terimindeki rassal şoklara karşı tepkisini ölçmektedir. Etki tepki fonksiyonunda hata teriminin verilen bir birimlik rassal şok karşısında endojen değişkenin tepkisini ölçmektedir.

\subsection{GARCH Modelleri}

Bu çalışmada, Bollerslev tarafından geliştirilmiş GARCH modelinden Standart GARCH $(1,1)$ formu varyans denklemi açıklayıcı değişkenlerle zenginleştirilerek kullanılmıştı. Buna göre $\mathrm{GARCH}$ modellerinde koşullu varyans aşağıdaki gibi modellenecektir: 


$$
\begin{gathered}
\varepsilon^{2}{ }_{t}^{\sim\left(0, h_{t}\right)} \\
h_{t}=\beta_{0}+\beta_{1} \varepsilon^{2}{ }_{t-1}+\beta_{2} h_{t-1}
\end{gathered}
$$

\subsection{Dinamik Koşullu Korelasyon GARCH Modelleri}

DCC-GARCH modeli GARCH tipi modellerin koşullu varyans ve kovaryanslar grubunda yer almaktadır. Bu grup içinde yer alan modellerin temel özelliği kovaryans matrisinin, $H_{t}$, standart sapmalar, $D_{t}$ ve korelasyon matrisi $R_{t}$ olarak ayrıştırılabilmesidir. DCC-GARCH modelde hem $D_{t}$ hem de $R_{t}$ zamanla değişen yapıda kullanılmaktadır. Buna göre $\mathrm{n}$ tane varlığın "0" beklenen değerli ve $H_{t}$ kovaryans matrisli getirilerini $\alpha_{t}$ ile ifade edersek DCC-GARCH model aşağıdaki gibi tanımlanabilir:

$$
\begin{aligned}
r_{t} & =\mu_{t}+\alpha_{t} \\
\alpha_{t} & =H_{t}{ }^{1 / 2} z_{t} \\
H_{t} & =D_{t} R_{t} D_{t}
\end{aligned}
$$

$r_{t}: \mathrm{n}$ tane varlığın $\mathrm{t}$ dönemine ait $1 \times \mathrm{n}$ boyutlu logaritmik getiri vektörü,

$\alpha_{t}: \mathrm{E}\left[\alpha_{t}\right]=0$ ve $\operatorname{Cov}\left[\alpha_{t}\right]=H_{t}$ olmak üzere $1 \times n$ boyutlu ortalama düzeltilmiş getiri vektörü,

$\mu_{t}$ : Koşullu $r_{t}^{\prime}$ nin $1 \times n$ boyutlu beklenen değer vektörü,

$H_{t}$ : t döneminde $\alpha_{t}$ 'nin n×n boyutlu koşullu varyans matrisi,

$H_{t}{ }^{1 / 2}: H_{t}{ }^{\prime}$ den Cholesky ayrıştırması ile elde edilebilen koşullu varyans matrisi

$D_{t}$ : t döneminde $\alpha_{t}$ 'nin koşullu standart sapma değerlerinin $\mathrm{n} \times \mathrm{n}$ boyutlu diyagonal matrisi,

$R_{t}: \alpha_{t}^{\prime}$ nin $\mathrm{n} \times \mathrm{n}$ boyutlu koşullu korelasyon matrisi

$Z_{t}: \mathrm{E}\left[Z_{t}\right]=0$ ve $\mathrm{E}\left[Z^{T}{ }_{t}\right]$ olmak üzere, $\mathrm{n} \times 1$ boyutlu bağımsız özdeş dağııma sahip hatalar vektörü olarak tanımlanmaktadır.

DCC-GARCH modelinin dejavantajlarından biri zamana bağlı koşullu korelasyon matrisinin pozitif tanımlı olması gerekliliğidir. $\mathrm{Ht}$ kovaryans matrisi için pozitif tanımlı olma zorunluluğu bulunsa da DCC model parametreleri üzerine konan kolay kısıtlamalar ile bu koşul sağlanabilmektedir. Pozitif tanımlı olma koşulunun sağlandığından emin olabilmek için $R_{t}$ korelasyon matrisinin pozitif tanımlı olması şarttır. $D_{t}$ ise zaten tüm diyagonel elemanları pozitif tanımlı olduğundan pozitif olma gerekliliğini sağlamaktadır. Buna ek olarak da $R_{t}$ korelasyon matrisi elemanlarının hepsinin 1'e eşit veya 1'den küçük olması gerekir. Buna göre:

$$
\begin{gathered}
R_{t}=\varrho_{t}^{* 1} \varrho_{t} \varrho_{t}^{* 1} \\
\varrho_{t}=\left(1-\varrho_{1}-\varrho_{2}\right) \bar{\varrho}+\varrho_{1} \varepsilon_{t-1} \varepsilon_{t-1}^{T}+\varrho_{2} \varrho_{t-1}
\end{gathered}
$$

Olduğunda $Q_{t}$ aşağıdaki gibi tahmin edilebilir;

$$
\varrho_{t}=\frac{1}{T} \sum_{t=1}^{T} \varepsilon_{t} \varepsilon_{t}^{T}
$$

Koşulsuz varyansın pozitif tanımlı olma kısıtı için tek değişkenli GARCH modelde gerekli koşulların yanı sıra a ve b parametreleri aşağıdaki kısıtları sağlamalıdır;

$\varrho_{1} \geq 0, \varrho_{2} \geq 0$ ve $\varrho_{1}+\varrho_{2}<1$

\subsection{Dalgacık (Wavelet) Analizi}

Bu araştırmada dalgacık uyumu (wavelet coherence-WTC) TÜFE-ÜFE ve TÜFE-Para Arzı'nın korelasyonlarını anlamak için kullanılmıştır. Enflasyon, üretici fiyat endeksi, para arzı değişimlerinin wavelet analizleri yapılarak 2018 kur şoku sonrası dönemde enflasyon üzerindeki etkileri analiz edilmiştir. Analizimizde Grinsted vd (2004) tarafından iki zaman serisi için geliştirilen dalgacık paketi uygulanmıştır. Serilerin birlikte hareketlerini dalgacık uyumu ile ölçülmektedir. Uyumlu alanlar kırmızıdan maviye renklerle temsil edillir ve iki seri arasında yüksekten düşüğe doğru korelasyonu göstermektedirler. Faz açısı seriler arasındaki nedensel ilişlileri anlamada bir göstergedir. Figürlerde, serilerin birlikte hareketine bakmak için oklardan yararlanmaktayız. Oklar bir zaman aralı̆̆ı boyunca sağa hareket ederse, seriler aynı fazdadırlar, bu nedenle bu zaman aralığında birlikte hareket ederler. Oklar aşağıyı gösteriyorsa birinci seri ikinciye neden olmaktadır, yukarıyı gösterdiğinde ise ikinci seri birinci seriyi etkileyendir. 
Sürekli Dalgacık Dönüşümü (continuous wavelet transform-CWT) zaman serisi tamamen ayrıştırılabilir ve sonra yeniden yapılandırılabilir. CWT, X(t) veri seti için bir bant geçiş eleği olarak çalışır ve katlamalı olarak tanımlanabilir;

$$
W_{x}(\tau, s)=\frac{1}{\sqrt{s}} \sum_{t=1}^{N} x(t) \varphi^{*}\left(\frac{t-\tau}{s}\right),
$$

Burada * karmaşık eşleniktir.

\subsubsection{Dalgacik Uyumu (Wavelet Coherence - WTC)}

Çapraz Dalgacık Dönüşümü CWT'lerden oluşur ve bu serilere frekans-zaman uzayında karşılıklı gücü ve tutarlı fazı ortaya çıkarır. Çapraz dalgacık dönüşümü aşağıdaki gibi tanımlanır;

$$
\Psi_{n}^{X Y}(s)=W_{n}^{X}(s) \cdot W_{n}^{Y *}(\mathrm{~s}) .
$$

Burada, $W_{n}^{X}(s)$ ve $W_{n}^{Y}, \mathrm{X}$ ve $\mathrm{Y}$ nin $C \mathrm{WT}^{\prime}$ leridir. $W_{n}^{Y *}$; ise $W_{n}^{Y \prime}$ nin karmaşık eşleniğidir.

Dalgacık uyumunun (WTC) formülü ise şu şekildedir;

$$
R_{n}^{2}(s)=\frac{\left|S\left(s^{-1} \Psi_{n}^{X Y}(s)\right)\right|^{2}}{S\left(s^{-1}\left|W_{n}^{X}(s)\right|^{2}\right) \cdot S\left(s^{-1} \mid\left(\left.W_{n}^{Y}(s)\right|^{2}\right)\right.}
$$

Burada, s dalgacık skalası, S ise düzgünleştirme operatorüdür.

\section{VERI SETI VE UYGULAMA SONUÇLARI}

Veri setleri aylık frekansta 01.01.2006-30.06.2020 dönemini kapsamaktadır. Bununla birlikte modeller oluşturulurken 01.01.2006-31.08.2018 (Kur şoku öncesi) ve 01.01.2006-30.06.2020 (Kur şoku sonrası Covid-19'u da içeren dönem) olmak üzere iki alt döneme parçalanarak veri setleri ayrı ayrı incelenmiştir.

Tablo 1: Veri Seti Açıklaması

\begin{tabular}{|l|l|l|l|}
\hline Seriler & Serilerin Açıklaması & Frekans & Kaynak \\
\hline TÜFE & Tüketici Fiyat Endeksi & Aylık & TÜik \\
\hline ÜFE & Üretici Fiyat Endeksi & Aylık & TÜik \\
\hline MS=Para arzı & M2 para arzı & Aylık & TCMB Evds \\
\hline Sanayi & Sanayi Üretim Endeksi & Aylık & TCMB Evds \\
\hline USDTRY & Dolar kuru & Aylık & TCMB Evds \\
\hline RTÜFE & TÜFE Değişimi & Aylık & \\
\hline RÜFE & ÜFE Değişimi & Aylık & \\
\hline RMS & MS Değişimi & Aylık & \\
\hline RSANAYi & Sanayi Değişimi & Aylık & \\
\hline RUSDTRY & USDTRY değiş̧imi & Aylık & \\
\hline
\end{tabular}

Model oluşturulmadan önce değişkenlerin durağanlık testi için Genişletilmiş Dickey Fuller (ADF) kullanılmış, ardından etki tepki analizleri ve DCC-GARCH modellerinin girdileri belirlenmiş, verilerin tanımlayıcı istatistiki bilgileri ise Tablo 2'te gösterilmiştir. Basıklık ve çarpıklık değerlerine baktığımızda Jarque-Bera değerlerinin de yükseklikleri de gösteriyor ki veriler normal dağılmamaktadır ${ }^{12}$. ADF testi sonuçları ise bütün verilerin durağan olduğunu göstermektedir. Değişkenlere ait tanımlayıcı istatistik değerleri Tablo 2' de belirtilmiştir.

\footnotetext{
${ }^{1}$ Verilerin dağılımının normal dağı̆ım gösterip göstermediğini belirlemenin bir diğer yolu ortalama, mod ve medyan değerlerine bakmaktır. Normal dağııımda bu değerler çakışıktır. Bu istatistikler birbirine yaklaşı̆̆ı ölçüde dağııım normal dağılıma yaklaşır. Birbirinden uzaklaşı̆̆ı ölçüde dağılım çarpıklaşır.

${ }^{2}$ Normal dağııımı test etmenin bir diğer yolu da basıklık ve çarpıkık katsayılarına bakmaktır. Çarpıklık (skewness) katsayısı normal dağılımda 0'dır. Negatif çarpıkıı katsayısı sağa çarpık dağıııma, pozitif çarpıklık katsayısı sola çarpık dağıııma işaret eder. Basıkıı (kurtosis) katsayısı da normal dağılımda 3 'tür. Pozitif basıklık katsayısı sivri dağılıma, negatif basıklık katsayııı ise basık bir dağıııma işaret eder.
} 
Tablo 2: Veri Tanımlayıcı İstatistikleri

\begin{tabular}{lccccc}
\hline & RTÜFE & RUFE & RUSDTRY & RSANAYI & RMS \\
\hline Ortalama & 0.0077 & 0.0079 & 0.0094 & 0.0047 & 0.0145 \\
Medyan & 0.0065 & 0.0063 & 0.0060 & 0.0028 & 0.0135 \\
Maksimum & 0.0611 & 0.1033 & 0.1880 & 0.3028 & 0.1111 \\
Minimum & -0.0145 & -0.0361 & -0.0866 & -0.3773 & -0.0420 \\
Std.Sap & 0.0089 & 0.0142 & 0.0376 & 0.1040 & 0.0182 \\
Çarpıklık (Skewness) & 1.3360 & 2.0414 & 1.2510 & -0.3737 & 1.1963 \\
Basıklık (Kurtosis) & 9.4766 & 15.1773 & 7.5383 & 3.7357 & 9.3668 \\
Jarque-Bera & 355.87 & 1195.93 & 194.70 & 7.97 & 335.38 \\
Olasılık & 0.00000 & 0.00000 & 0.00000 & 0.01856 & 0.00000 \\
Gözlem SayıSı & 174 & 174 & 174 & 174 & 174 \\
\hline
\end{tabular}

Modellerimizde kullanılmak üzere aylık logaritmik değişimler $r_{t}$, aşağıdaki hesapalama ile türetilmiştir:

$$
r_{t}=\frac{\ln \left(S_{t}\right)}{\ln \left(S_{t-1}\right)}
$$

Figür 2'de açıkça görüldüğü gibi 2018 ağustos ayında yaşanan kur şokundan sonra enflasyon, üretci fiyatları, dolar kuru ve para arzında ciddi volatilite gözlemlenmiştir.

Figür 2: Enflasyon, Üretici Fiyatları, Petrol Fiyatları, Para arzı ve Döviz Kuru Değişimleri

RTÜFE
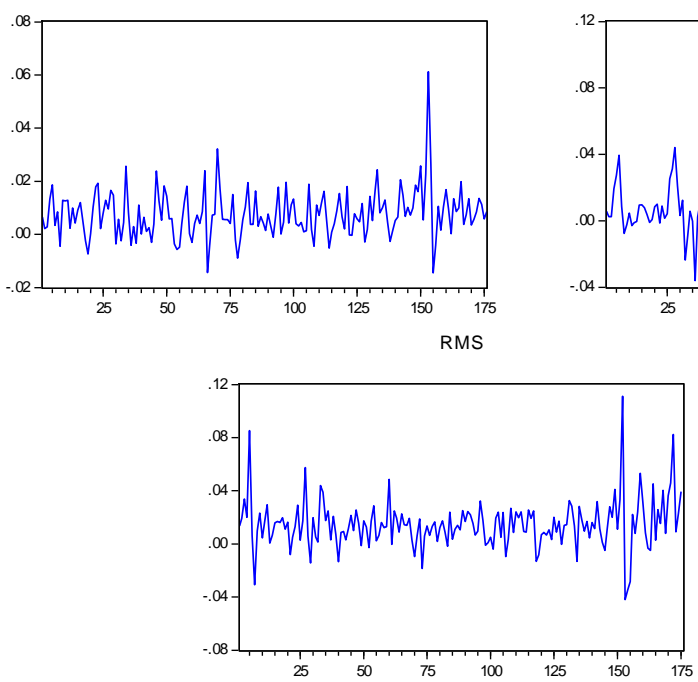

RUFE

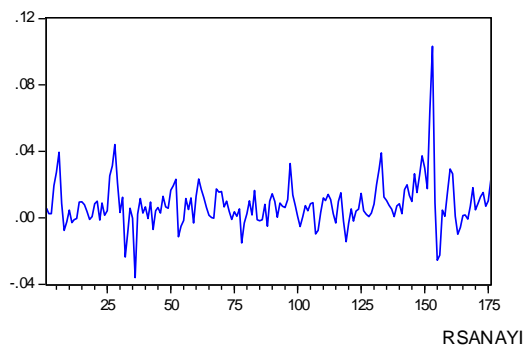

RUSDTRY

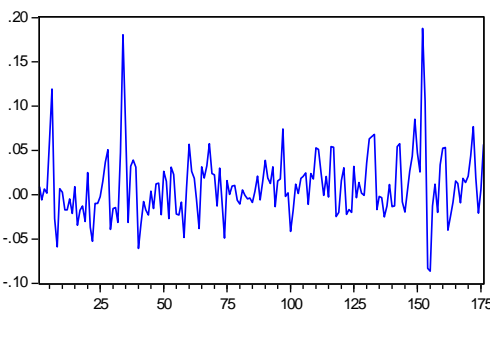

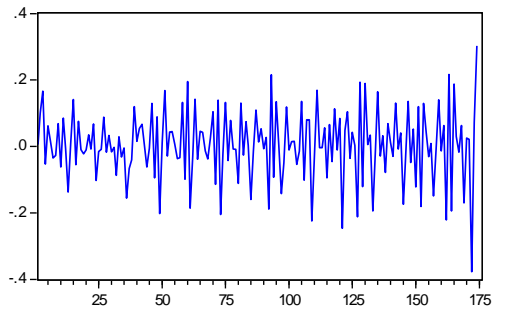

Bu hususlardan yola çıkarak enflasyon, üretici fiyat endeksi, para arzı, petrol fiyatları ve döviz kuru değişimlerinin etki-tepki ve varyans ayrıştırma analizleri yapılarak 2018 kur şoku sonrası dönemde enflasyon üzerindeki etkileri analiz edilmiştir. Etkitepki fonksiyonları daha önce de bahsettiğimiz gibi VAR analizi ile bulunan ve rassal hata terimlerinden birindeki bir standart sapmalık şokun içsel değişkenlerin şimdiki ve gelecekteki değerlerine olan etkisini gösteren fonksiyonlardır.

Grafiklerdeki sürekli çizgiler modelin hata teriminde meydana gelen 1 standart sapmalık şoka karşılık içsel değişkenin zaman içinde verdiği tepkileri göstermektedir. Kesikli çizgiler ise \pm 2 standart sapma için elde edilen güven aralıklarını ifade etmektedir. Bu bağlamda enflasyon için 12 dönemlik (aylık) 4 gecikmeli VAR modelinden elde edilen Etki Tepki Analizi sonuçları Figür $3^{\prime}$ de sunulmaktadır. Değişkenler $I(0)$ olarak bulunduklarından VAR modeline düzey halleri ile dahil edilmişlerdir. 
Etki tepki analizlerine göre, enflasyon oranı değişkeni endojen verilen bir birimlik standart şok karşısında yaklaşık bir çeyrek dönem istatistiki olarak anlamlı ve negatif yönde tepki vermektedir. Sonuçlar hem 2018 kur şoku öncesi hem de bütün veri setini kapsayan 2020 Haziran sonuna kadar olan iki dönem için de değişmez iken 2020 haziran dönemine kadar olan veri setine göre 12 aylık dönem sonunda dengeye geldiğini söyleyebiliriz. Bu sonuçlar da 2018 kur şoku sonrası ve 2020 Haziran arasındaki dönemde enflasyonun, endojen şoklarından kalıcı bir şekilde etkilendiği sonucuna varmamıza neden oldu. Her iki dönem için enflasyonun para arzı, döviz kuru sanayi endeksi ve üretici fiyat endeksine verilen şoklara benzer tepkiler verdiği görülürken etkilerin 12 aylın dönem sonunda dengeye gelmeye yaklaştığı gözlemlenmiştir.

Figür 3: Etki-Tepki Analizleri

\section{6-2018 (Ă̆ustos)}

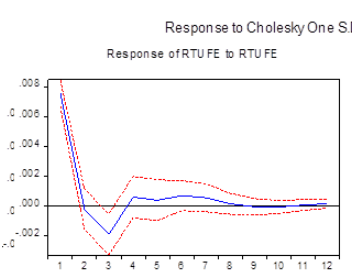

Response ofRTUFE to RMS

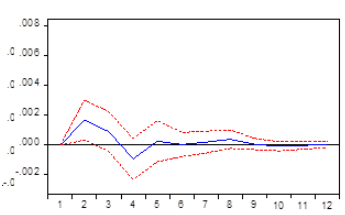

Response ofRTUFE to RSANA

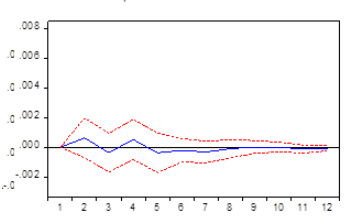

2006-2020 (Haziran)

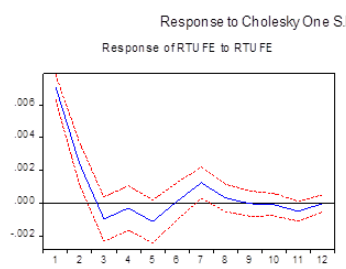

Response ofRTUFE to RMS
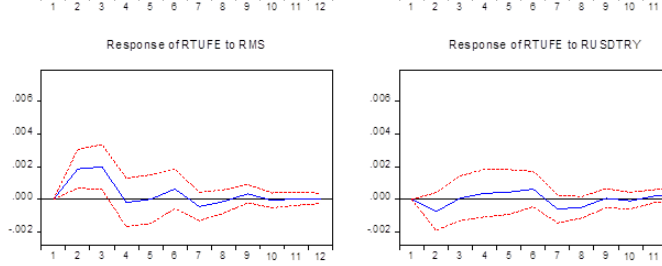

Response ofRTUFE to RU SDTRY

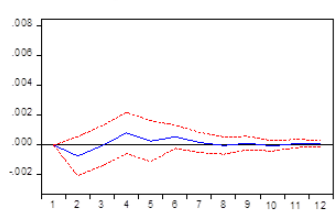

Response ofRTUFE to RSANA

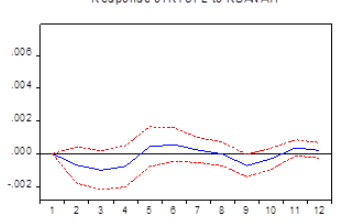

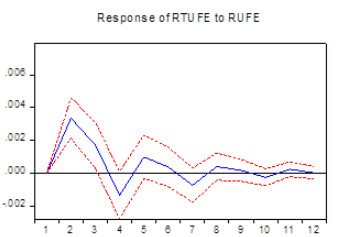

Response ofRTUFE to RU SDTR

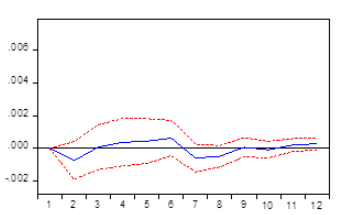

Bu noktada iki dönemin sonuçlarını birbirinden daha net bir şekilde ayırmamızı sağlayacak olan analiz Varyans ayrıştırma analizidir. Varyans ayrıştırma analizi sonuçlarına göre 2018 kur krizi öncesi enflasyonun kendi içsel şoklarından daha fazla etkilenirken 2018 ağustos sonrası dönemin de dahil edildiği haziran 2020 sonuna kadar olan dönemde endojen şokların etkisi azalırken para arzı ve üretici fiyat endeksi etkisinin arttığı gözlemlenmiştir (Figür 4). Bu göre, 2018 Ağustos sonuna kadar olan dönemde TÜFE endojen şoklar, ÜFE, MS, USDTRY ve Sanayi'nin varyans ayrıştırma tablosundaki bir çeyrek (4 dönem) sonraki değerleri sırasıyla 87.86, 2.76, 6.42, 1.75 ve 1.18 iken bu değerler, 2020 Haziran sonuna kadar olan dönemde aynı sırayla $68.60,19.16,8.94,0.82$ ve 2.46 olarak değişmiştir. Bu bağlamda kur şokundan sonra ilk göze çarpan bulgu enflasyon varyansına endojen şokların etkisinin azaldı̆̆ı, ÜFE, MS, USDTRY ve SANAYi'nin arttığı gözlemlenmişir.

Swap işlemleri, kamu bankarlı ile bir süre 6.85 seviyelerinde sabit tutulan kur seviyeleri, düşen sermaye yatırımları, artan işsizliğin yanında iş gücü piyasasından çekilen emek arzı, kurdaki atakların girdi maliyetlerini arttırması nedeniyle yerine koyma maliyetlerini de arttıracak olması kur geçişkenliğinin de habercisi niteliğindedir. 
Figür 4: Varyans Ayrıştırma Analizleri

2006-2018 (Ağustos)

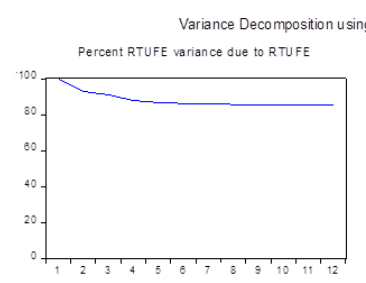

Percent RTUFE variances due to RMS

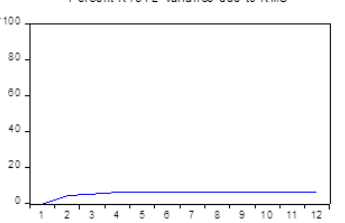

Percent RTUFE variance due to RSANA)

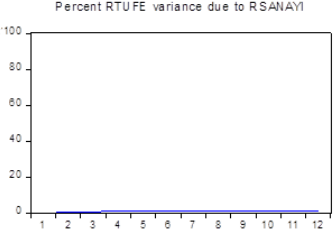

2006-2020 (Haziran)

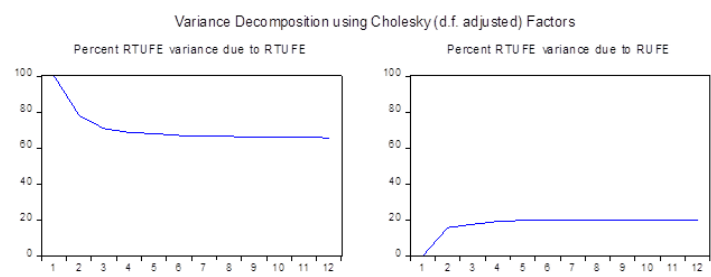

Percent RTUFE variance due to RIIS

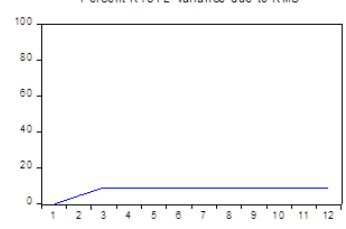

Percent RTUFE variance due to RU SDTRY

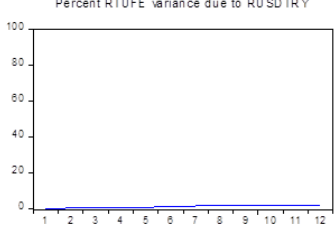

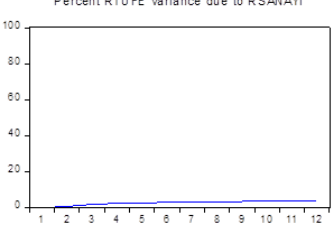

Bu bilgiler ışığında hem 2006-2018 Ağustos hem de 2006-2020 Haziran dönemleri için oluşturduğumuz GARCH modelleri Tablo 3'te gösterilmiştir. Para arzındaki artış, faiz oranları ve döviz kurlarındaki yükselme, fiyatlar genel seviyesindeki yükselmenin temel faktörleri arasında gösterilebilir. Bu bağlamda enflasyonla maliyet yönünden mücadelede döviz kurları ve faiz oranlarının düşük tutulması gerekmektedir. Enflasyonla talep yönünden mücadelede ise para arzının azaltılması ile ilgili politika önerileri getirilmektedir. Ancak fiyatlar genel seviyesindeki yükselme, döviz kurlarındaki yükselmenin ya da artan nominal bütçe açıkları yolu ile para arzındaki ve faiz oranlarındaki artışın da bir sebebi olarak gösterilebilmektedir. Buna karşın GARCH modellerinde kur şoku öncesinde enflasyon değişimi ile para arzı arasında istatistiki olarak anlamı bir ilişki yokken kur şoku sonrasını da kapsayan modelde bu ilişki anlamlı fakat genel literatürün aksine negatif yönlü ve açıklanmaya muhtaçtır.

Covid-19 sürecinde para basılarak hazineye verilip gereken ödemeler yapılmıştır. Para piyasada kalmasın diye de basılan paranın bir kısmı döviz satılarak geri toplanmıştır. Bunu da döviz rezervlerindeki azalıştan görebiliyoruz. Paranın toplanma sebebi ise enflasyonu denetlemek ve faiz artışının önüne geçmek. Aksi taktirde Merkez Bankası faiz artırmak zorunda kalacak ve bu durum karar alıcılar tarafından desteklenmeyen bir olasılıktır³. Fakat gerek rezervlerdeki azalış gerekse Merkez Bankası'nın gösterge faizi arttırmama yönündeki kararları neticesinde döviz kuru hızla artarak maliyetlere yansımış bunun sonucu olarak da enflasyon yükselmiş ve para arzı ile enflasyon arasında bu ezber bozan ilişkiye neden olmuştur. Tüfe'nin 4. gecikmeye kadar yani bir çeyrek öncesine kadar modellere dahil edilmesi büyük ölçüde anlamlı olmaları enflasyon ataletinden de bahsetmemizi gerektiriyor. Enflasyon Ataleti, enflasyonu düşürmek için uygulanan politikalara karşın, iktisadi karar birimlerinin geçmiş dönem ki enflasyon beklentilerini sürdürmeleri nedeniyle, enflasyon oranının düşmeye karşı direnç göstermesi ve yapışkan hale gelmesidir. Kur şoku sonrası ÜFE, MS ve USDTRY'nin enflasyon varyanslarındaki etkisi artsa da enflasyon varyanslarındaki endojen yapı hala oldukça güçlü seyretmektedir. Para arzı GARCH modellerine göre ise yine enflasyondaki değişimin artması ile para arzındaki değişimin negatif yönlü olduğu görülmüştür. Burada da yukarıdaki hususların geçerli olduğunu belirtebilirz. Son olarak maliyet ayağına baktığımızda ÜFE değişimlerinin kur geçişkenliğinin de etkisiyle USDTRY değişimlerinden pozitif ve yine para arzındaki değişimlerden de pozitif yönde etkilendiğini görmekteyiz.

Burada GARCH modelleri ile açıklığa kavuşturulması gereken husus getiri denklemlerinden ziyade varyans modelleri yani volatilite davranışlarıdır. Her üç model için de kur şoku sonrası dönemde toplam haber etkisinin azaldığını görürken kısa vadeli

\footnotetext{
${ }^{3}$ http://www.mahfiegilmez.com/2020/04/covid-19-para-basm-ve-imfnin-yeni-imkan.html
} 
şokların volatilite üzerindeki etkilerinin arttığını görüyoruz. Bu durum yine kur geçişkenliği ve kısa vadeli para politikası uygulamalarının enflasyon, üretici maliyetleri ve para arzının volatiliteler üzerindeki baskın etkilerini ortaya çıkarıyor.

Tablo 3: GARCH Modelleri

\begin{tabular}{|c|c|c|c|c|c|c|c|c|c|c|c|c|}
\hline \multicolumn{13}{|c|}{ 2006-2018 (Ağustos) } \\
\hline & \multicolumn{4}{|c|}{ TÜFE } & \multicolumn{4}{|c|}{ ÜFE } & \multicolumn{4}{|c|}{ MS } \\
\hline & \multicolumn{2}{|c|}{ Getiri Denklemi } & \multicolumn{2}{|c|}{ Varyans Denklemi } & \multicolumn{2}{|c|}{ Getiri Denklemi } & \multicolumn{2}{|c|}{ Varyans Denklemi } & \multicolumn{2}{|c|}{ Getiri Denklemi } & \multicolumn{2}{|c|}{ Varyans Denklemi } \\
\hline & katsayı & z-istatistiği & katsayı & z-istatistiği & katsayı & z-istatistiği & katsayı & z-istatistiği & katsayı & z-istatistiği & katsayı & z-istatistiği \\
\hline C & 0.0076 & 6.8836 & & & 0.0010 & 1.1753 & & & 0.0118 & 9.5526 & & \\
\hline RMS & -0.0556 & -1.1979 & & & 0.1909 & 13.6334 & & & & & & \\
\hline RUSDTRY & 0.0339 & 1.9604 & & & 0.3408 & 4.9839 & & & 0.2828 & 9.2462 & & \\
\hline RTÜFE & & & & & & & & & -0.2554 & -2.2136 & & \\
\hline RTÜFE(-1) & 0.1233 & 1.4223 & & & & & & & & & & \\
\hline RTÜFE(-2) & -0.1858 & -2.2314 & & & & & & & & & & \\
\hline RTÜFE(-3) & 0.1078 & 1.2783 & & & & & & & & & & \\
\hline RTÜFE(-4) & -0.3498 & -4.6593 & & & & & & & & & & \\
\hline RUFE & 0.3058 & 5.1167 & & & & & & & 0.0742 & 0.7576 & & \\
\hline RUFE(-1) & & & & & 0.3566 & 4.7524 & & & & & & \\
\hline$\alpha_{0}$ & & & 0.0000 & 0.8239 & & & 0.0000 & 1.7080 & & & 0.0000 & 1.8896 \\
\hline$\alpha_{1}$ & & & 0.0741 & 1.2243 & & & 0.2792 & 2.1718 & & & 0.3436 & 1.9976 \\
\hline$\beta_{1}$ & & & 0.8513 & 6.9151 & & & 0.4971 & 2.0986 & & & 0.5782 & 5.4521 \\
\hline Gözlem Sayısı & & & & 152 & & & & 152 & & & & 152 \\
\hline$R^{2}$ & & & & 0.3309 & & & & 0.5323 & & & & 0.3480 \\
\hline DW & & & & 2.0894 & & & & 1.7272 & & & & 2.0016 \\
\hline
\end{tabular}

\begin{tabular}{|c|c|c|c|c|c|c|c|c|c|c|c|c|}
\hline \multicolumn{13}{|c|}{ 2006-2020 (Haziran) } \\
\hline & \multicolumn{4}{|c|}{ TÜFE } & \multicolumn{4}{|c|}{ ÜFE } & \multicolumn{4}{|c|}{ MS } \\
\hline & \multicolumn{2}{|c|}{ Getiri Denklemi } & \multicolumn{2}{|c|}{ Varyans Denklemi } & \multicolumn{2}{|c|}{ Getiri Denklemi } & \multicolumn{2}{|c|}{ Varyans Denklemi } & \multicolumn{2}{|c|}{ Getiri Denklemi } & \multicolumn{2}{|c|}{ Varyans Denklemi } \\
\hline & katsayı & $z$-istatistiği & katsayı & z-istatistiği & katsayı & z-istatistiği & katsayı & $z$-istatistiği & katsayı & z-istatistiği & katsayı & z-istatistiği \\
\hline C & 0.0071 & 6.7885 & & & 0.0005 & 0.6964 & & & 0.0124 & 10.9341 & & \\
\hline RMS & -0.0815 & -2.1548 & & & & & & & & & & \\
\hline RUSDTRY & 0.0332 & 2.0123 & & & 0.1785 & 16.1690 & & & 0.2831 & 11.7408 & & \\
\hline RTÜFE & & & & & 0.3725 & 6.0844 & & & -0.2540 & -2.6309 & & \\
\hline RTÜFE(-1) & 0.2033 & 3.4271 & & & & & & & & & & \\
\hline RTÜFE(-2) & -0.2280 & -3.0301 & & & & & & & & & & \\
\hline RTÜFE(-3) & 0.1591 & 1.9115 & & & & & & & & & & \\
\hline RTÜFE(-4) & -0.2530 & -4.3096 & & & & & & & & & & \\
\hline RUFE & 0.3101 & 7.8016 & & & & & & & & & & \\
\hline RUFE(-1) & & & & & 0.3878 & 6.2870 & & & & & & \\
\hline$\alpha_{0}$ & & & 0.0000 & 0.9981 & & & 0.0000 & 3.5046 & & & 0.0000 & 1.7896 \\
\hline$\alpha_{1}$ & & & 0.1121 & 1.7143 & & & 0.4646 & 3.0511 & & & 0.3767 & 3.3703 \\
\hline$\beta_{1}$ & & & 0.7656 & 5.0386 & & & 0.1927 & 1.2123 & & & 0.6112 & 8.4943 \\
\hline Gözlem Sayısı & & & & 174 & & & & 176 & & & & 175 \\
\hline$R^{2}$ & & & & 0.4470 & & & & 0.6333 & & & & 0.3125 \\
\hline DW & & & & 2.0938 & & & & 1.8662 & & & & 2.0603 \\
\hline
\end{tabular}

Son olarak, DCC-GARCH $(1,1)$ modeli daha önce de belirtildiği gibi iki getiri serisi arasında koşullu korelasyonun zamanla değiştiğini varsaymaktadır. Figür 5'te Enflasyon-Üretici Fiyat Endeski ile Enflasyon-Para Arzı modelleri için DCC-GARCH grafikleri gösterilmiştir. Enflasyon ve Üretici Fiyat Endeksi DCC-GARCH modellerine baktığımızda döviz kuru şoku öncesi 
dönemde dinamik koşullu korelasyon -0.3 ve 0.2 bandındayken kur şoku sonrası dönemi de içeren modelde CC -0.1 ve 0.1 bandında seyrediyor.

Figür 5: DCC-GARCH Modelleri

2006-2018 (Ağustos) TÜFE-ÜFE

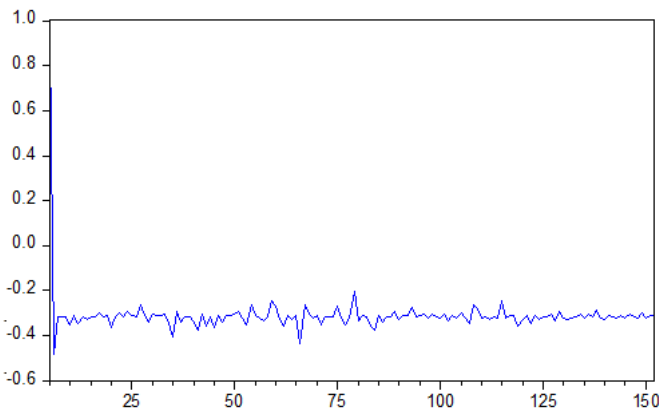

2006-2018 (Ağustos) TÜFE-MS

$\mathrm{RHO12}$

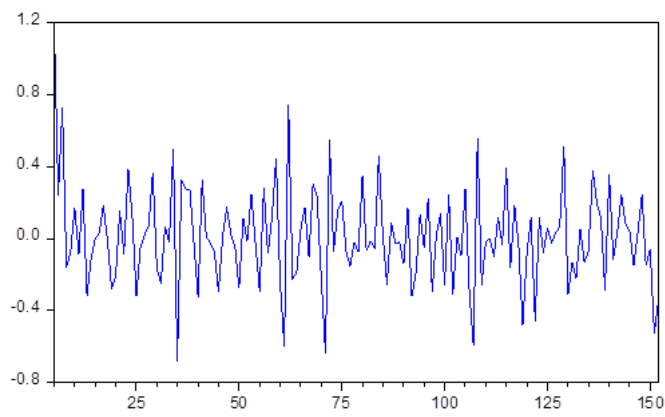

2006-2020 (Haziran) TÜFE-ÜFE

$\mathrm{RHO} 12$

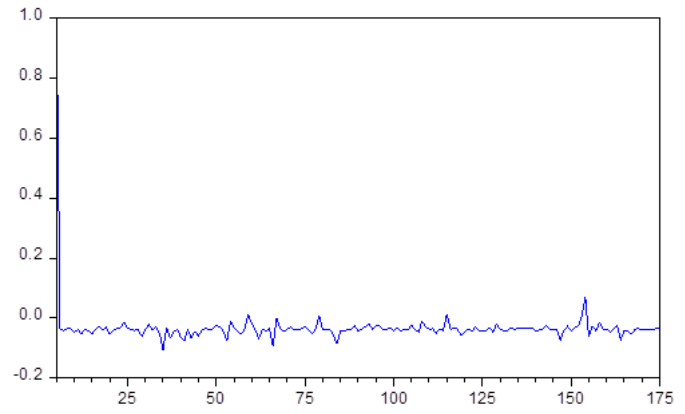

2006-2020 (Haziran) TÜFE-MS

RHO12

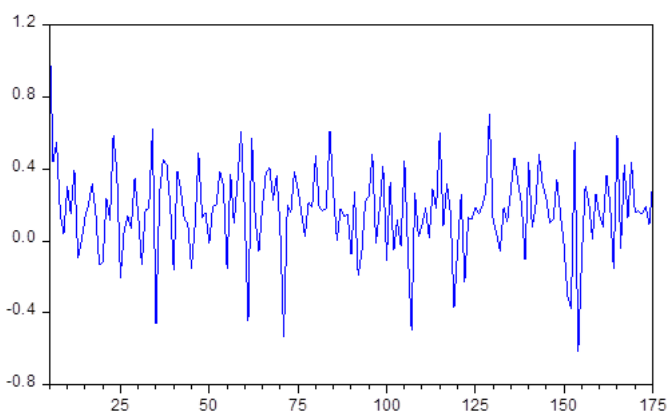

DCC-GARCH modelinden elde edilen sonuçlar Tablo 4'te gösterilmiştir. Burada daha önce de belirttiğimiz gibi $Q_{1}$ ve $Q_{2}$ dinamik koşullu korelasyon katsayıları olarak bilinmektedir. DCC-GARCH modeli özelliklerine göre dinamik koşullu korelasyon katsayıları negatif olmamalı ve durağanlığın sağlanması için de toplamlarının birden küçük olması gerekmektedir. Eğer $Q_{2} 1^{\prime}$ e çok yakın bir değer alırsa o zaman süreç Sabit Korelasyon'a yakınsar. Dolayısıyla süreci dinamik yapan $Q_{1}$ kısmıdır. Fakat Francq ve Zakoian (2010)'a göre iki tür GARCH sürecinden bahsedebiliriz. Birinci duruma göre GARCH sürecindeki arch ve garch katsayıları negatif olsa bile istatistiki olarak anlamlı ise buna yarı-güçlü, eğer hem pozitif hem de istatistiki olarak anlamlı ise güçlü GARCH süreci olarak tanımlanır.

$Q_{1}$ dinamik koşullu korelasyon üzerindeki kısa vadeli şokların kalıılık derecesini ifade ederken, $Q_{1}+Q_{2}$, dinamik koşullu korelasyon üzerindeki uzun vadeli kalıcılık derecesini belirtmektedir. Her dört model içinde hesaplanan $Q_{1}$ ve $Q_{2}$ katsayıları görülmektedir. TÜFE-ÜFE arasındaki dinamik koşullu korelasyon katsayıları \%10 anlamlılık düzeyinde bile anlamlı bulunmamıştır ve $Q_{2}$ negatiftir.

TÜFE-MS arasındaki dinamik koşullu korelasyon katsayıları \%1 anlamlılık düzeyinde (2006-2020 Haziran dönemi için TÜFE-MS modelindeki $Q_{2}$ hariç) bile anlamlı bulunmamıştır fakat $Q_{2}$ negatiftir. Dinamik koşullu korelasyon üzerinde kısa dönem şokların kalıcılık derecesi varyansların kalıcılık derecesine göre daha yüksek olduğu görülmektedir. Dolayısıyla, dinamik koşullu korelasyon zamana bağlı olarak geçmiş varyanslardan daha az etkilenmektedir. Bu durumu GARCH modellerinde de gördüğümüz gibi Merkez Bankası'nın palyetif ve kısa vadeli para politikalarına bağlamamız çok da yanlış olmayacaktır. 
Tablo 4: DCC-GARCH Korelasyon Katsayıları

\begin{tabular}{|c|c|c|c|c|}
\hline & Katsayı & z-istatistiği & Olasılık & AIC \\
\hline$\varrho_{1}$ & 0.0331 & 0.6218 & 0.5341 & 5.5789 \\
\hline$\varrho_{2}$ & -0.1217 & -0.0437 & 0.9651 & \\
\hline Gözlem Sayısı & 148 & & & \\
\hline
\end{tabular}

\begin{tabular}{|c|c|c|c|c|}
\hline \multicolumn{5}{|c|}{ 2006-2020 (Haziran) TUFE-UFE } \\
\hline & Katsayı & z-istatistiği & Olasılık & AIC \\
\hline$\varrho_{1}$ & 0.0173 & 0.3809 & 0.7033 & 5.6758 \\
\hline$\varrho_{2}$ & -0.0024 & -0.0006 & 0.9995 & \\
\hline Gözlem Sayısı & 171 & & & \\
\hline
\end{tabular}

\begin{tabular}{|c|c|c|c|c|}
\hline \multicolumn{5}{|c|}{ 2006-2018 (Ağustos) TÜFE-MS } \\
\hline & Katsayı & z-istatistiği & Olasılık & AIC \\
\hline$Q_{1}$ & 0.3298 & 14.8333 & 0.0000 & 5.9564 \\
\hline$\varrho_{2}$ & -0.1996 & -3.0063 & 0.0026 & \\
\hline Gözlem Sayısı & 148 & & & \\
\hline
\end{tabular}

\begin{tabular}{|c|c|c|c|c|}
\hline & Katsayı & z-istatistiği & Olasılık & AIC \\
\hline$\varrho_{1}$ & 0.3325 & 24.1618 & 0.0000 & 6.0563 \\
\hline$\varrho_{2}$ & -0.0172 & -0.1697 & 0.8653 & \\
\hline Gözlem Sayısı & 171 & & & \\
\hline
\end{tabular}

ARCH sınıfı modeller özellikle yüksek frekanslı zaman serisi verilerine gösterdiği uyumla dikkat çekmektedir. Yüksek frekanslı finansal verilerle yapılan birçok ampirik uygulamada $\alpha_{1}+\beta_{1}$ toplamı bire çok yakın çıkmaktadır. Bu durum Bütünleşik GARCH (IGARCH) olarak adlandırılan modelin Engle ve Bollerslev (1986) tarafından geliştirilmesine ampirik olarak dayanak teşkil etmiştir. IGARCH sınıfı modellerde $[(\alpha(L)+\beta(L))]$ polinomu birim köke sahip olduğundan, koşullu varyansa gelen bir şok kalıcı olmakta ve gelecek dönem tahminlerinin yapılmasındaki önemini uzun bir süre boyunca korumaktadır. Bu bağlamda kullanılan veri setlerinin aylık frekansı olmaları da DCC-GARCH yönteminin bütün modellerde çok iyi çalışmamasının nedenlerinden biri olabilir.

Figür 6'da ki dalgacık uyum grafikleri, özellikle yüksek periyotlarda çeşitli ölçeklerde koherans alanlarının (kırmızı bölgeler) bulunduğunu anlatmaktadır. Neredeyse tüm zaman aralığı için koherent alanlar 16 aylık dönemli dalgalanmalardan sonra görülmektedir. En düşük korelasyonun olduğu alanlar periyodu 16 aya kadar olan dalgalanmalarda Agu.07 (ay20) ve Tem.16(ay128) arasında karşımıza çıkmaktadır. Bu da bize belirtilen dönemde enflasyonun para arzı ve üretici fiyat endeksine bağlı hareket etmediğini göstermektedir. Oklar, tüm zaman aralıklarında kararlı bir resim çizmemiştir. Oklar karmaşık bir şekilde sağa ve sola doğru bakmaktadırlar. Bu da bize serilerin harektlerlerinin pozitif fazda yani aynı yönde olup olmadığı konusunda net bir sonuç vermemektedir. WTC: TÜFE-ÜFE figüründeki kırmızı bölgeler bize iki seri arasındaki corelasyonun diğer çifte göre daha yüksek olduğunu göstermektedir. Enflasyon ve üretici fiyat endeksi arasındaki ilişkinin TÜFE - Para Arzına göre fazla olduğu gözlenmiştir.

Figür6: WTC: TÜFE-ÜFE-ParaArzı 2006-2018.

Yatay eksendeki tarihler 20: Agu.07, 40:Nis.09, 60:Ara.10, 120:Ara.15, 130:Eki.16

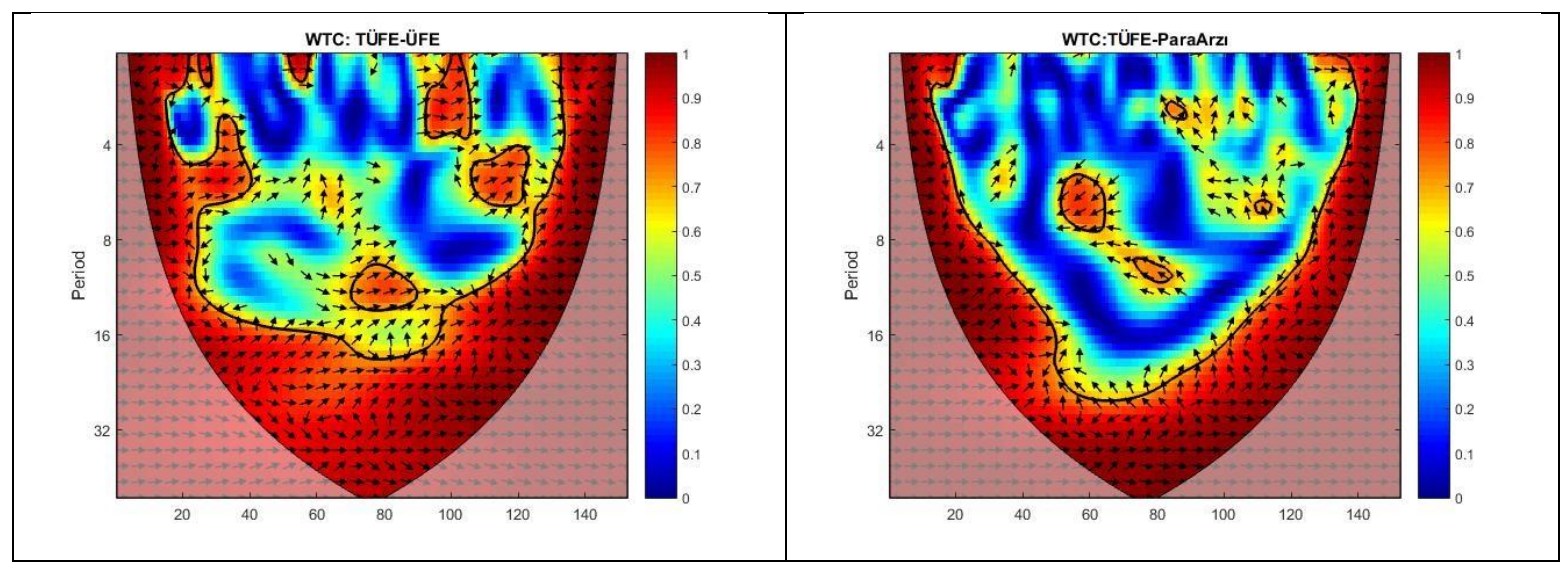

Figür 7'de, 2006-2020 döneminde, zaman serileri Ağustos 2018(kur şoku) sonrası (beyaz çizgi-ay150) kırmızı alanlardan da görüldüğü üzere yüksek korelasyon göstermişlerdir. 2018 kur şoku sonrası okların sağa doğru yöneldiği yani TÜFE-ÜFE, TÜFEParaArzı çiftlerinin tek bir seri halinde pozitif anlamda birlikte hareket ettiklerini göstermektedir. Kur şoku öncesi okların aşağı ve yukarı yönlerine net bir yorum yapılamasa da bundan sonraki zaman diliminde he iki grafikte okların yukarı yönde olduğunu yani kur şoku sonrası üretici fiyat endeksi ile para arzından enflasyon tarafına daha eksojen bir nedensellik olduğu sonucu 
çıkmaktadır. Kur şoku sonrası enflasyonun diğer iki göstergeden etkilendiği wavelet analizleri sonucunda piyasa verileri ile örtüşecek şekilde karşımıza çıkmıştır.

Figür7: WTC: TÜFE-ÜFE-ParaArzı 2006-2020.

Yatay eksendeki tarihler 20:Agu.07, 40:Nis.09, 60:Ara.10, 120:Ara.15, 140:Ağu.17

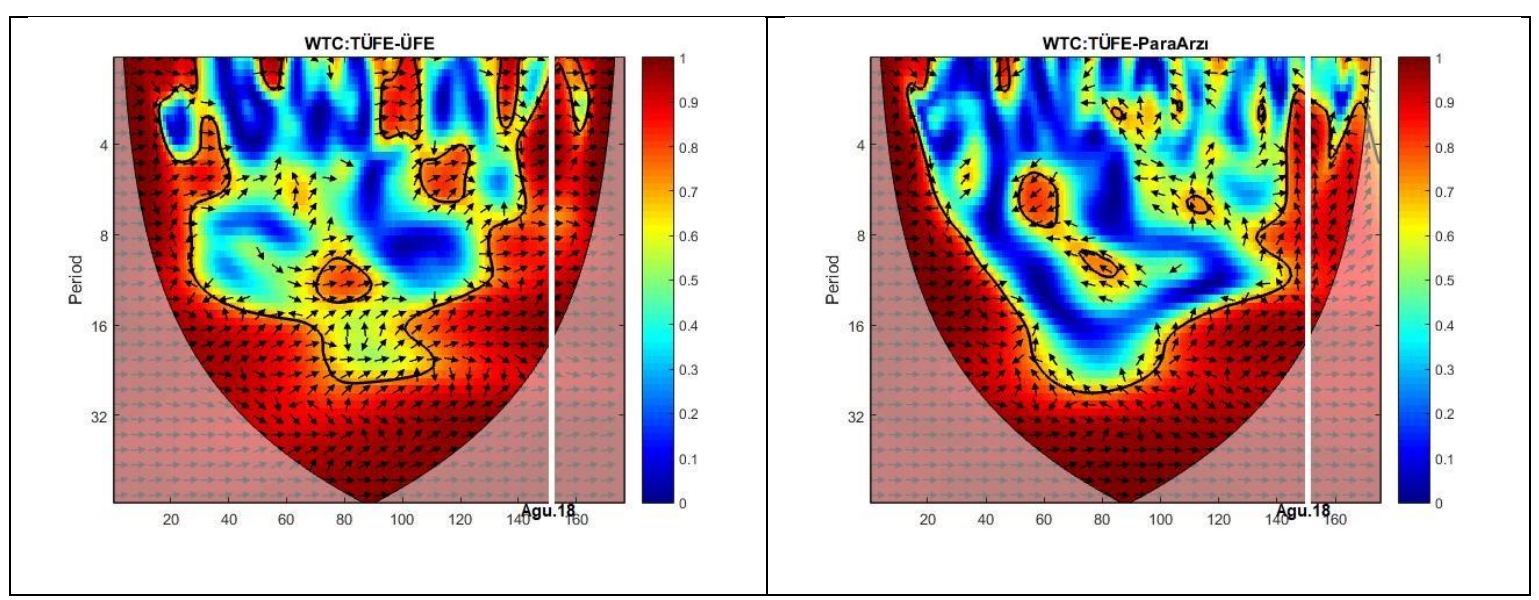

\section{SONUÇ VE ILERI ARAŞTIRMA KONULARI}

Döviz kurlarını serbest piyasa ekonomisinin mekanizmaları dışında baskıda tutulursa bir noktada rezervler tükenip kur yönetilememe noktasına geldiğinde olumsuz etkisi yapay olumlu etkisinden çok daha fazla olmaktadır. Bu bağlamda 2018 ağustos sonrası piyasada enflasyonu düşürmek için öncelikle kura baskı yapılmaya çalışıldı. Zira kurlar arttıkça döviz fiyatlarına bağlı mal ve hizmetlerin fiyatı da ona göre artmaya başlar. Mal ve hizmet fiyatlarının artması önce üretici fiyatlarına ve daha sonra da biraz gecikmeli olarak tüketici fiyatlarına yansır.

Swap işlemleri, kamu bankarlı ile bir süre 6.85 seviyelerinde sabit tutulan kur seviyeleri, düşen sermaye yatırımları, artan işsizliğin yanında iş gücü piyasasından çekilen emek arzı, kurdaki atakların girdi maliyetlerini arttırması nedeniyle yerine koyma maliyetlerini de arttıracak olması kur geçişkenliğinin de habercisi niteliğindedir.

TÜFE-MS arasındaki dinamik koşullu korelasyon katsayıları \%1 anlamlılık düzeyinde (2006-2020 Haziran dönemi için TÜFE-MS modelindeki $Q_{2}$ hariç) bile anlamlı bulunmamıştır fakat $Q_{2}$ negatiftir. Dinamik koşullu korelasyon üzerinde kısa dönem şokların kalııılık derecesi varyansların kalıılık derecesine göre daha yüksek olduğu görülmektedir. Dolayısıyla, dinamik koşullu korelasyon zamana bağlı olarak geçmiş varyanslardan daha az etkilenmektedir. Bu durumu GARCH modellerinde de gördüğümüz gibi Merkez Bankasının palyetif ve kısa vadeli para politikalarına bağlamamız çok da yanlış olmayacaktır.

WTC figürleri, kur şoku sonrası dönemde serilerin çok yüksek koherens alanlarına sahip olduğunu göstermektedir, bu nedenle WTC sonuçları da Etki-Tepki ve VAR Analizi sonuçları ile uyumludur ve özellikle Ağustos 2018-Ağusotos 2020 döneminde TÜFEÜFE ve TÜFE-ParaArzı'nın birlikte hareket ettiğini ve enflasyonun, ÜFE ve para arzından etkilendiğini ifade etmektedir.

Bu bağlamda kullanılan veri setlerinin aylık frekanslı olmaları da DCC-GARCH yönteminin bütün modellerde iyi çalışmamasının nedenlerinden biri olabilir. Görüldüğü gibi özellikle gözümüzün her dakika döviz kuru, faiz oranları ve borsa hisse fiyat değişimlerde olduğu gerçeği ışığında, onları en çok etkileyen bir enflasyon verisinin olmaması büyük bir eksiklik olarak karşımıza çıkmakta ${ }^{4}$. Bu nedenle oluşmakta olan günlük enflasyon verileri de yeterli çokluğa ulaştıktan sonra bu çalışma kapsamındaki modellerin tekrar test edilmesinin yararlı olacağı görüşündeyiz. Günlük üretici fiyat endeksleri henüz hesaplanmıyor olsa da döviz kuru üzerinden giderek enflasyona direk etkisi ile geçişkenlik analizleri yapılabilecektir.

\footnotetext{
${ }^{4}$ Enflasyon Araştırma Grubu (ENAG) Türkiye'de bu amaçla, sadece günlük değil, saatlik ve hatta önümüzdeki dönemlerde dinamik seyreden zamansız bir fiyat endeksi elde etmek için yola çıkmışır. ENAG ayrıca akademik çalışmalarda, özellikle de zaman serilerine dayalı ekonomik modellemelerde yokluğu hissedilen fiyat endekslerinin oluşturulması faiz ile işsizliğin ve faiz ile enflasyonun kestiriminde önemli bir tartışmayı da sonlandıracaktır. ENAG enflasyon yaklaşımı ayrıca merkez bankası para politikasının dinamik karar verme sürecine de ışık tutabilmesi açııından önem kazanacaktır. Dinamik karakterinden dolayı, ENAG Enflasyon Endeksi tüketim alışkanlıklarında meydana gelecek değişimleri bünyesinde daha hızlı bir şekilde ayarlamaya olanak sağlayacaktır.
} 


\section{KAYNAKÇA}

Abdioğlu, Z., ve Korkmaz, Ö, (2012). Tüketici ve Üretici Fiyat Endeksi Arasında Fiyat Geçişkenliği: Alt Sektörler, Çukurova Üniversitesi IiiBF Dergisi, 16(2), ss. 65-81.

Akçay, S. (2011). The causal relationship between producer price index and consumer price index: Empirical evidence from selected European countries, International Journal of Economics and Finance, 3(6), 227-232.

Altıntaş, H. (2014). Türkiye'de Döviz Kurunun Enflasyon Üzerşne Geçiş Etkísinin Ekonometrik Analizi: 1987-2011. Uludag Journal of Economy \& Society, 33(1), 163-201.

Caporale, G. M., Katsimi, M., ve Pittis, N., (2002). Causality links between Consumer and Producer Prices: Some Empirical Evidence, Southern Economic Journal, 68, ss.703-711.

Çatalbaş-Karpat, G., (2007), Türkiye'de Para Arzı ile Enflasyon arasındaki İlişkinin Parametrik Olmayan Regresyon Analizi ile İncelenmesi. Gazi Üniversitesi Đktisadi ve Đdari Bilimler Fakültesi Dergisi 9/3. 197 - 212

Demirgil, B. (2019). Türkiye'de Enflasyonun Belirleyicileri Üzerine Uygulamalı Bir Çalışma. Journal of International Management Educational and Economics Perspectives, 7 (1) , 13-21 . Retrieved from https://dergipark.org.tr/tr/pub/jimeep/issue/46348/525238

Dorestani, A., ve Arjomand L.H., (2006). An Empirical Study of the Relationship Between Consumer and Price Index: A Unit Root Test and Test of Cointegraion, The Coastal Business Journal Spring, Vol:5, No:1 ss. 33-38.

Francq, Christian and Zakoian, Jean-Michel (2010): QML estimation of a class of multivariate GARCH models without moment conditions on the observed process, MPRA Paper No. 20779

Grinsted, A., Moore J. C., and Jevrejeva S. (2004). Application of the cross wavelet transform and wavelet coherence to geophysical time series. Non-linear Processes in Geophysics 11, 561-566.

İslatince, Y., (2017). Para Arzı ve Enflasyon İlişkisi: Türkiye İçin Nedensellik Analizi (1988-2016) . Anadolu Üniversitesi Sosyal Bilimler Dergisi, 17 (3) , 43-56. DOI: 10.18037/ausbd.417274

Kaya, M., Öz, E. (2016). Enflasyon, Bütçe Açığı ve Para Arzı Iliş̧isinin Türkiye Ekonomisi Açısından Değerlendirilmesi: 1980-2014 Dönemi. Yönetim ve Ekonomi: Celal Bayar Üniversitesi İktisadi ve İdari Bilimler Fakültesi Dergisi, 23 (3) , 639-651 . DOI: 10.18657/yonveek.281800

Saraç, T.B ve Karagöz, K., (2010). “Türkiye'de Tüketici ve Üretici Fiyatları Arasındaki İlişki: Yapısal Kırılma ve Sınır Testi, Maliye Dergisi, 159, ss.220-232.

Tiwari, A. K. (2012), Decomposing Time-Frequency Relationship between Interest Rates and Share Prices in India through Wavelets, MPRA Paper No. 39693 